\title{
Interaction between nutrition and Eimeria acervulina infection in broiler chickens: development of an experimental infection model
}

\author{
BY C. ADAMS, H. A. VAHL AND A. VELDMAN* \\ CLO-Institute for Animal Nutrition 'De Schothorst', PO Box 533, 8200 AM Lelystad, \\ The Netherlands
}

(Received 4 January 1994 - Revised 27 March 1995 - Accepted 19 September 1995)

\begin{abstract}
In three experiments broiler chickens were inoculated with sporulated Eimeria acervulina oocysts at $18 \mathrm{~d}$ of age. Feed intake, body-weight gain, brush-border enzyme activities, fat digestion, protein digestion and protein retention were measured. Body-weight gain was reduced during the acute phase of the infection and increased during the recovery phase of the infection. Feed intake was decreased on day 4 and day 5 postinfection (PI) and increased from day 7 to day 11 PI. Maltase (EC 3.2.1.20) and sucrase (EC 3.2.1.48) activities were decreased on day 5 PI in all intestinal segments. In Expts 2 and 3, however, maltase activity was increased in the ileum. Fat digestion was decreased from day 2 to day 11 PI. N digestion and retention were decreased from day 2 to day 11 PI.
\end{abstract}

Poultry: Coccidiosis: Infection model

Coccidiosis in chickens is an intestinal infection caused by protozoa that invade the mucosal epithelium. Coccidiosis is characterized by reduced body-weight gain of the host and malabsorption of ingested nutrients (Turk, 1978). Eimeria acervulina affects a specific part of the intestinal tract, i.e. the duodenum and part of the jejunum.

Morphological changes in the affected area include shortened or flattened villi, decreased villous surface and elongated crypts (Fernando \& McCraw, 1973). Decreased activities of digestive enzymes located on the upper half of the villi, such as disaccharidases, indicate a damaged brush border with a decreased digestive absorptive capacity.

The aim of the present study was to obtain an experimental infection model in broiler chickens in order to examine effects that an infection, that merely affects duodenum and part of the jejunum, can have on digestion and absorptive capacities. In three experiments the effects of an Eimeria acervulina infection on feed intake, body-weight gain, disaccharidase activities, fat digestion, protein digestion and protein retention were measured. Expt 1 was used as a pilot experiment. The highest level of infection of Expt 1 was rounded up in Expt 2, in which a pair-fed control was used in order to eliminate effects of reduced feed intake. In Expt 3 lower levels of infections were chosen in order to follow dose-response effects.

\section{MATERIALS AND METHODS}

Animals and diet

Female, Ross broiler chickens were obtained as 1-d-old birds, from a commercial hatchery. Chickens were kept in groups on electrically heated wire-floored batteries under constant lighting. Unmedicated feed and water were available ad libitum, unless stated otherwise. All

* For reprints. 
diets were formulated to meet or exceed the nutritional requirements of broilers as given by the National Research Council (1984). Body-weight gain and feed intake were measured throughout the experiments. The broilers were inoculated per os with Eimeria acervulina oocysts at $18 \mathrm{~d}$ of age, unless stated otherwise.

\section{Experimental design}

In Expt 1, each of the treatments consisted of two replicates with ten birds per replicate. The treatments were inoculations with 0,280000 or 560000 sporulated oocysts of Eimeria acervulina, which were obtained from Janssen Pharmaceutica (Beerse, Belgium).

In Expt 2 each of the three treatments was made up of three replicates with twelve chicks per replicate. The treatments were inoculations with 0 or 600000 sporulated oocysts of Eimeria acervulina. In the third treatment the broilers were pair-fed and not inoculated. These birds received an amount of feed equal to that consumed by inoculated birds during the preceding $24 \mathrm{~h}$. Pair-fed controls were fed in groups. Excreta were collected during five time periods after the infection.

The five treatments in Expt 3 were made up of two replicates each and ten birds per replicate. For practical reasons the inoculation in the first replicate was on day 16 while the inoculation of the other replicate was on day 18 as usual. The inoculation doses were 0 , $50000,100000,200000$ and 400000 sporulated oocysts of Eimeria acervulina. For Expts 2 and 3 oocysts were furnished by the Poultry Health Institute (Doorn, The Netherlands).

\section{Lesion score}

Scoring of lesions in Expt 3 was based on the description of Johnson \& Reid (1970). A lesion score can range from 0 , which indicates no visible lesions, to +4 , which indicates the most severe lesions.

\section{Analytical procedures}

Preparation of mucosal samples. In all experiments, on day 5 postinfection (PI), three to four birds per replicate were killed and the entire small intestine was removed and immediately iced. For analysis small intestines were divided into three segments based on external anatomical markers: duodenum, from the junction with the gizzard to the cystic duct; jejunum, from the cystic duct to the yolk sac diverticulum; and ileum, from the yolk sac diverticulum to the ileocaecal junction. Segments were cut open longitudinally and the intestinal contents were removed. The segments were weighed and mucosal villi were scraped off. Scrapings were homogenized with $3 \mathrm{ml}$ ice-cold saline $(9 \mathrm{~g} \mathrm{NaCl} / 1)$ using an IKA Ultra-Turrax (IKA Werke, Janke \& Kunkel GmbH \& Co KG, Stanfen, Germany). Portions of the homogenate were frozen at $-80^{\circ}$ until further analysis.

Disaccharidase activities. Maltase (EC 3.2.1.20) and sucrase (EC 3.2.1.48) activities were determined using the method of Dahlqvist (1964). A test-combination (Boehringer Mannheim GmbH, Germany cat. no. 124036) was used to measure spectrophotometrically the end-product glucose. $\mathrm{N}$ concentrations of mucosal scrapings were determined using a Bio-Rad protein assay (Bio-Rad Laboratories, Veenendaal, The Netherlands) according to the method of Bradford (1976). Data from mucosal scrapings were pooled per replicate.

Nitrogen. $\mathrm{N}$ concentrations were determined in feed and excreta samples using the Kjeldahl technique.

Uric acid. Uric acid was extracted from excreta using a saturated $\mathrm{Li}_{2} \mathrm{CO}_{3}$ solution. Uric acid was then determined in the extract by adding uricase $(E C$ 1.7.3.3) and tungstenphosphoric acid. Extinction was measured after $20 \mathrm{~min}$ at $700 \mathrm{~nm}$.

Fat. Fat concentration was measured gravimetrically in feed and excreta samples by extracting samples with hexane after hydrolysing with $3 \mathrm{M}-\mathrm{HCl}$. 
Acid-insoluble ash. Acid-insoluble ash was determined gravimetrically in feed and excreta samples because diatomaceous earth (Diamol) was used as an indigestible marker to enable calculation of digestion and retention of nutrients. After hydrolysing with $3 \mathrm{M}-\mathrm{HCl}$, samples were filtered and washed. Residues were ashed at $550^{\circ}$.

\section{Calculations}

Fat digestion was calculated by subtracting the fat concentration of excreta from the dietary fat concentration. Dietary fat concentration and fat concentration in excreta had to be corrected for marker concentration. Protein retention was calculated in a similar manner.

$$
\text { Fat digestion }(\%)=\frac{F_{\text {leed }} / \mathbf{M}_{\text {feed }}-\mathbf{F}_{\text {excreta }} / \mathbf{M}_{\text {excreta }}}{F_{\text {leed }} / \mathbf{M}_{\text {feed }}} \times 100,
$$

where $F$ is fat concentration and $M$ is acid-insoluble ash concentration.

To calculate protein digestion a distinction had to be made between urinary $\mathrm{N}$ and faecal N (Terpstra \& De Hart, 1974).

$$
\text { Protein digestion (\%) }=\frac{\mathbf{N}_{\text {feed }} / \mathbf{M}_{\text {reed }}-\left(\mathbf{N}_{\text {excreta }}-1,20 \mathbf{N}_{\text {uricactd }}\right) / \mathbf{M}_{\text {excreta }}}{N_{\text {feed }} / \mathbf{M}_{\text {feed }}} \times 100,
$$

where $\mathbf{N}$ is nitrogen concentration.

\section{Statistical procedure}

Analysis was based on group means. Treatment effects were determined using a one-way ANOVA achieved through the application of multiple regression procedures (Snedecor \& Cochran, 1980). The level of significance was set at $5 \%$.

\section{RESULTS}

Shortly after the infection with Eimeria acervulina, body-weight gain and feed intake were reduced. Feed conversion (feed intake/body-weight gain) was increased (Table 1, Expt 1). The effects were dose related.

In Expt 2 body-weight gain was reduced from day 3 to day 6 PI while it was increased from day 6 to day 12 PI. Feed intake was significantly reduced on day 4 and day 5 PI. Meanwhile feed intake was significantly increased from day 7 to day 11 PI (Fig. 1). Although feed intake over the total PI period was the same in both experimental groups, body weight did not completely recover over the total experimental period. Feed intake of the pair-fed control group did not differ significantly from that of the infected group (results not shown). However, body-weight gain of the pair-fed control group was significantly increased in comparison with the infected group during all time periods except from days 0 to 3 PI. Performance results for Expt 3 are not shown.

In Expt 1 maltase activity was significantly reduced in the jejunum and ileum at day 5 PI (Table 2). Sucrase activity, however, was only reduced in the duodenum. In Expts 2 and 3 maltase activity decreased in the duodenum while there was a significant increase in the ileum. In addition, in Expt 2 maltase activity was significantly reduced in the jejunum. The effects on activities of disaccharidases were dose related in Expt 1. In Expt 3 no dose-related effects became apparent because of the large deviation around the means. In Expt 2 maltase activity of the pair-fed control group was significantly increased in the jejunum and ileum in comparison with the control group that had free access to feed.

On day 6 PI no lesions in any of the intestinal segments of the control group were found. 
Table 1. Effect of Eimeria acervulina infection on body-weight gain, feed intake and feed conversion in broiler chickens*

(Mean values for twenty (Expt 1) or twenty-four birds (Expt 2) per treatment)

\begin{tabular}{|c|c|c|c|c|c|c|c|c|}
\hline \multicolumn{2}{|c|}{ Infection dose $\dagger$} & \multirow{2}{*}{\begin{tabular}{|c|}
$\begin{array}{c}\text { Body-weight gain } \\
(\mathrm{g})\end{array}$ \\
Day ... 16-23
\end{tabular}} & & & & & \multirow{2}{*}{$\begin{array}{c}\begin{array}{c}\text { Feed intake } \\
(\mathrm{g})\end{array} \\
16-23\end{array}$} & \multirow{2}{*}{$\frac{\text { Feed conversion }}{16-23}$} \\
\hline & & & & & & & & \\
\hline Expt 1 & $\begin{array}{l}0 \\
280000 \\
\text { S60000 } \\
\quad \text { LSD }\end{array}$ & $\begin{array}{c}304 \\
235 \\
201 \\
11 \\
\text { qua. lin }\end{array}$ & & & & & $\begin{array}{r}501 \\
432 \\
407 \\
26 \\
\text { lin }\end{array}$ & $\begin{array}{l}1.65 \\
1.84 \\
2.02 \\
0.20 \\
\text { lin }\end{array}$ \\
\hline & & Day ... 18-21 & $21-24$ & $24-27$ & $27-30$ & $18-30$ & & $18-30$ \\
\hline Expt 2 & $\begin{array}{l}0 \\
600000 \\
0, \text { pair-fed } \\
\quad \text { LSD }\end{array}$ & $\begin{array}{r}110 \\
113 \\
90 \\
4\end{array}$ & $\begin{array}{r}106 \\
34 \\
63 \\
26\end{array}$ & $\begin{array}{r}125 \\
137 \\
156 \\
9\end{array}$ & $\begin{array}{r}127 \\
141 \\
151 \\
22\end{array}$ & $\begin{array}{r}468 \\
426 \\
460 \\
20\end{array}$ & & $\begin{array}{l}1.83 \\
2.01 \\
1.89 \\
0 \cdot 15\end{array}$ \\
\hline
\end{tabular}

LSD, least significant difference, based on ANOVA for two residual df; qua, quadratic effect; lin, linear effect.

* For details of procedures, see pp. 867-867.

$\dagger$ Broilers were infected with sporulated Eimeria acervulina oocysts on day 18.

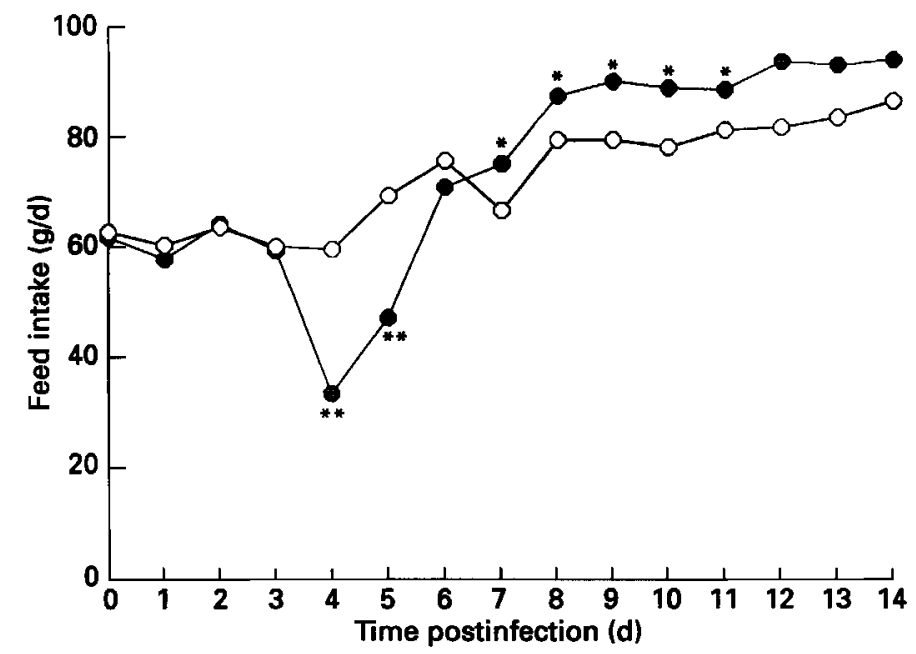

Fig. 1. Expt 2. Effect of Eimeria acervulina infection on feed intake in broiler chickens. Broilers were infected with $0(O)$ or $600000(\Theta)$ sporulated Eimeria acervulina oocysts at $18 \mathrm{~d}$ of age. Mean values were significantly different: ${ }^{*} P<0.05 ;{ }^{* *} P<0.01$. For details of procedures, see pp. 867-868.

In all infected groups a lesion score of +2 or +3 was found in the duodenum and jejunum, while no lesions were found in the ileum.

From days 2 to $11 \mathrm{PI}$, fat digestion was significantly reduced (Table 3). Protein digestion and retention were significantly reduced on days 2 to 8 PI. As total amounts of uric acid that were determined in excreta were significantly higher for infected groups (results not shown), differences in protein retention were higher than differences in protein digestion. Digestion and retention values for pair-fed controls were not significantly different from those of ad libitum-fed control groups. 
Table 2. Effect of Eimeria acervulina infection on activities of mucosal brush border enzymes in broiler chickens*

(Mean values for six to eight birds per treatment)

\begin{tabular}{|c|c|c|c|c|c|c|c|}
\hline \multirow{2}{*}{\multicolumn{2}{|c|}{ Infection dose $\dagger$}} & \multicolumn{3}{|c|}{$\begin{array}{c}\text { Maltase }(E C 3.2 .1 .20) \\
\quad(\mathrm{U} / \mathrm{g} \text { protein })_{\ddagger}^{*}\end{array}$} & \multicolumn{3}{|c|}{$\begin{array}{l}\text { Sucrase }(E C 3.2 .1 .48) \\
\quad(\mathrm{U} / \mathrm{g} \text { protein) } \ddagger\end{array}$} \\
\hline & & $\mathrm{D}$ & $\mathbf{J}$ & $I$ & $\mathrm{D}$ & $\mathrm{J}$ & $\bar{I}$ \\
\hline Expt 1 & $\begin{array}{l}0 \\
280000 \\
560000 \\
\quad \text { LSD }\end{array}$ & $\begin{array}{r}113 \\
56 \\
48 \\
80\end{array}$ & $\begin{array}{c}267 \\
129 \\
117 \\
70 \\
\text { qua. lin }\end{array}$ & $\begin{array}{r}146 \\
76 \\
60 \\
82 \\
\text { lin }\end{array}$ & $\begin{array}{c}29 \\
8 \\
6 \\
10 \\
\text { qua. lin }\end{array}$ & $\begin{array}{l}44 \\
26 \\
26 \\
19\end{array}$ & $\begin{array}{l}13 \\
13 \\
11 \\
12\end{array}$ \\
\hline Expt 2 & $\begin{array}{l}0 \\
600000 \\
0, \text { pair-fed } \\
\quad \text { LSD }\end{array}$ & $\begin{array}{r}219 \\
28 \\
220 \\
28\end{array}$ & $\begin{array}{l}324 \\
204 \\
464 \\
109\end{array}$ & $\begin{array}{r}119 \\
292 \\
237 \\
75\end{array}$ & & & \\
\hline Expt 3 & $\begin{array}{l}0 \\
50000 \\
100000 \\
200000 \\
400000 \\
\text { LSD }\end{array}$ & $\begin{array}{r}143 \\
91 \\
87 \\
68 \\
39 \\
75 \\
\text { lin }\end{array}$ & $\begin{array}{l}211 \\
225 \\
239 \\
296 \\
229 \\
121\end{array}$ & $\begin{array}{l}140 \\
225 \\
311 \\
320 \\
295 \\
112\end{array}$ & & & \\
\hline
\end{tabular}

LSD, least significant difference, based on ANOVA for two residual df in Expts 1 and 2 and for four residual df in Expt 3; D, duodenum; J, jejunum; I, ileum; qua, quadratic effect; lin, linear effect.

* For details of procedures, see pp. 867-869.

† Broilers were infected with sporulated Eimeria acervulina oocysts on day 18.

$\ddagger$ One unit $(\mathrm{U})$ is the amount of enzyme that breaks down $1 \mu \mathrm{mol}$ substrate per min at $37^{\circ}$.

Table 3. Expt 2. Effect of Eimeria acervulina infection on fat digestion, protein digestion and protein retention in broiler chickens*

(Mean values for twenty-four birds per treatment)

\begin{tabular}{|c|c|c|c|c|c|}
\hline & \multirow[b]{2}{*}{ Day } & \multicolumn{3}{|c|}{ Infection dose $†$} & \multirow[b]{2}{*}{ LSD } \\
\hline & & 0 & 600000 & 0 (pair-fed) & \\
\hline Fat digestion (\%) & $\begin{array}{l}20-23 \\
23-26 \\
26-29 \\
29-31\end{array}$ & $\begin{array}{l}81 \\
80 \\
81 \\
80\end{array}$ & $\begin{array}{l}45 \\
25 \\
76 \\
78\end{array}$ & $\begin{array}{l}81 \\
80 \\
80 \\
80\end{array}$ & $\begin{array}{r}11 \\
17 \\
1 \\
3\end{array}$ \\
\hline Protein digestion (\%) & $\begin{array}{l}20-23 \\
23-26 \\
26-29 \\
29-31\end{array}$ & $\begin{array}{l}81 \\
79 \\
79 \\
79\end{array}$ & $\begin{array}{l}73 \\
68 \\
79 \\
78\end{array}$ & $\begin{array}{l}78 \\
77 \\
77 \\
77\end{array}$ & $\begin{array}{l}8 \\
7 \\
3 \\
3\end{array}$ \\
\hline Protein retention (\%) & $\begin{array}{ll}20 & -23 \\
23 & -26 \\
26 & -29 \\
29 & -31\end{array}$ & $\begin{array}{l}57 \\
54 \\
58 \\
55\end{array}$ & $\begin{array}{l}41 \\
38 \\
57 \\
54\end{array}$ & $\begin{array}{l}51 \\
54 \\
54 \\
52\end{array}$ & $\begin{array}{r}10 \\
5 \\
3 \\
4\end{array}$ \\
\hline
\end{tabular}

LSD, least significant difference, based on ANOVA for two residual df.

* For details of procedures, see pp. 867-869.

+ Broilers were infected with sporulated Eimeria acervulina oocysts on day 18. 


\section{DISCUSSION}

Coccidiosis is an infectious disease that reduces body-weight gain as a result of combined effects of reduced feed intake, reduced digestion of nutrients, decreased absorption of digested nutrients and changes in metabolism.

First, in coccidiosis feed intake and feed conversion ratio are reduced. This characteristic has been described by many authors (reviewed by Crompton, 1976). However, reduced feed intake is not the only factor that leads to reduced body-weight gain in coccidiosis. As shown in Expt 2, body-weight gain in the Eimeria acervulina-infected group was much more affected than in the pair-fed control group, although feed intake was the same.

Decreased digestion of nutrients also contributes to decreased body-weight gain in coccidiosis. In experiments with Eimeria acervulina Major \& Ruff (1978a) found reduced sucrase and maltase activities in the duodenum. Allen (1987) found reduced sucrase activities in the duodenum as well as in the jejunum in experiments with Eimeria acervulina but an increase in sucrase activity in the ileum. In the present study there was an increase in maltase activity in the ileum.

In Expt 3 reduced maltase activities were found in the duodenum, which was most severely affected by the infection, while there was an increase in maltase activity in the ileum, where no lesions were found. This compensatory enzyme activity might be a result of substrate induction. Disaccharides that are not hydrolysed enzymically in the proximal end of the intestine might induce enzyme activities more distally.

However, results for ileal disaccharidase activity in Expt 1 were not in line with results of Expts 2 and 3. Unfortunately oocysts were from different strains and in addition no lesions were scored in Expt 1 so results cannot be compared.

The precise mechanism of reduced fat digestion in Eimeria acervulina infection is not clear. For optimal fat digestion bile salts are needed to emulsify fat. Lipase (EC 3.1.1.3) is necessary for hydrolysis of triacylglycerols. Reduction of other pancreatic enzyme activities, e.g. amylase (EC 3.2.1.1), can contribute to reduced nutrient utilization during coccidiosis (Major \& Ruff, 1978b). Absorptive capacities might be reduced as a result of morphological changes including shortened villi and reduced villous surface (Fernando \& McCraw, 1973).

As a result of the Eimeria acervulina infection a reduction in $\mathrm{N}$ retention was found in Expt 2. This means that the difference between net intestinal $\mathbf{N}$ uptake and $\mathbf{N}$ release in faeces and urine was reduced. Net intestinal $\mathbf{N}$ uptake might be decreased as a result of decreased absorptive capacity but Turk (1972) found no differences in protein absorption during the acute phase of an infection with Eimeria acervulina. In addition, Ruff \& Wilkins (1980) found that overall absorptive capacity of L-methionine did not change, although there were differences in absorption capacity of the affected and non-affected intestinal areas of the Eimeria acervulina-infected broilers. Reduced net intestinal $\mathbf{N}$ uptake might also be a result of leakage of plasma proteins into the intestinal lumen (Joyner et al. 1975). In addition, $\mathbf{N}$ release in urine was increased as shown by increased uric acid concentrations in excreta of infected animals in Expt 2.

During infections a general pattern is seen of decreased feed intake and increased protein requirement (Beisel, 1985). During infection extra protein is used for gluconeogenesis as glucose is used as energy source for increased energy demands. To a lesser extent amino acids are used for the synthesis of new proteins required for the host's defence mechanism. As a result of increased protein needs muscle protein has to be broken down. Sharma \& Fernando (1975) found decreased deposition of tissue protein during the acute phase of an infection with Eimeria acervulina.

The present study shows that an infection with Eimeria acervulina affects nutrient utilization in chickens. This infection model will be used to test different diet compositions 
in which nutrient utilization might be improved during the acute phase and the recovery phase of the infection. With this infection model it is possible to measure fat and $\mathrm{N}$ digestion which are better indicators of improvement of the course of the infection than performance results.

The authors wish to thank G. Braem of Janssen Pharmaceutica, Beerse, Belgium and H. W. Peek and M. H. Vertommen of the Poultry Health Institute, Doorn, The Netherlands for kindly providing Eimeria acervulina oocysts. This study was financially supported by the Dutch Department of Economics.

\section{REFERENCES}

Allen, P. C. (1987). Physiological responses of chicken gut tissue to coccidial infection: comparative effects of Eimeria acervulina and Eimeria mitis on mucosal mass, carotenoid content and brush border enzyme activity. Poultry Science 66, 1306-1315.

Beisel, W. R. (1985). Nutrition and infection. In Nutritional Biochemistry and Metabolism with Clinical Applications, pp. 369-394 [M. C. Lindner, editor]. New York: Elsevier Applied Science Publishers.

Bradford, M. M. (1976). A rapid and sensitive method for quantitation of microgram quantities of protein utilising the principle of protein-dye binding. Analytical Biochemistry 72, 248-254.

Crompton, D. W. T. (1976). Malfunction of the gut: parasitism. In Digestion in the Fowl, pp. 193-345 [K. N. Boorman and B. M. Freeman, editors]. Edinburgh: British Poultry Science Ltd.

Dahlqvist, A. (1964). Method for assay of intestinal disaccharidases. Analytical Biochemistry 7, 18-25.

Fernando, M. A. \& McCraw, B. M. (1973). Mucosal morphology and cellular renewal of chickens following a single infection of Eimeria acervulina. Journal of Parasitology 59, 493-501.

Johnson, J. \& Reid, W. M. (1970). Anticoccidial drugs: lesion scoring techniques in battery and floor-pen experiments with chickens. Experimental Parasitology 28, 30-36.

Joyner, L. P., Patterson, D. S. P., Berrett, S., Boarer, C. D. H., Cheong, F. H. \& Norton, C. C. (1975). Aminoacid malabsorption and intestinal leakage of plasma-proteins in young chicks infected with Eimeria acervulina. Avian Pathology 4, 17-33.

Major, J. R. \& Ruff, M. D. (1978a). Disaccharidase activity in the intestinal tissue of broilers infected with coccidia. Journal of Parasitology 64, 706-711.

Major, J. R. \& Ruff, M. D. (1978b). Eimeria spp. : influence of coccidia on digestion (amylolytic activity) in broiler chickens. Experimental Parasitology 45, 234-240.

National Research Council (1984). Nutrient Requirements of Poultry, 8th ed. Washington: National Academy Press.

Ruff, M. D. \& Wilkins, G. C. (1980). Total intestinal absorption of glucose and L-methionine in broilers infected with Eimeria acervulina. E. mivati, E. maxima or E. brunetti. Parasitology 80, 555-569.

Sharma, V. D. \& Fernando, M. A. (1975). Effect of Eimeria acervulina infection on nutrient retention with special reference to fat malabsorption in chickens. Canadian Journal of Comparative Medicine 39, 146-154.

Snedecor, G. W. \& Cochran, W. G. (1980). Statistical Methods, 7th ed. lowa: Iowa State University Press.

Terpstra, K. \& De Hart, N. (1974). The estimation of urinary nitrogen and faecal nitrogen in poultry excreta. Zeitschrift für Tierphysiologie, Tierernährung und Futtermittelkunde 32, 306-320.

Turk, D. E. (1972). Protozoan parasitic infections of the chick intestine and protein digestion and absorption. Journal of Nutrition 102, 1217-1222.

Turk, D. E. (1978). The effect of coccidiosis on intestinal function and gut microflora. In Avian Coccidiosis, pp. 227-267 [P. L. Long, K. N. Boorman and B. M. Freeman, editors]. Edinburgh: British Poultry Science Ltd. 